ARTICLE

\title{
Nanomolar phosphate supply and its recycling drive net community production in the subtropical North Pacific
}

Fuminori Hashihama (1) 1,2凶 , Ichiro Yasuda ${ }^{3}$, Aki Kumabe ${ }^{1}$, Mitsuhide Sato ${ }^{4,5}$, Hiroshi Sasaoka ${ }^{1}$, Yosuke lida (1) ${ }^{6}$, Takuhei Shiozaki $^{3}$, Hiroaki Saito (1) ${ }^{3}$, Jota Kanda ${ }^{1}$, Ken Furuya ${ }^{4,7}$, Philip W. Boyd (D) ${ }^{2}$ \& Masao Ishii (i] ${ }^{8}$

Seasonal drawdown of dissolved inorganic carbon (DIC) in the subtropical upper ocean makes a significant contribution to net community production (NCP) globally. Although NCP requires macronutrient supply, surface macronutrients are chronically depleted, and their supply has been unable to balance the NCP demand. Here, we report nanomolar increases in surface nitrate plus nitrite $(\mathrm{N}+\mathrm{N}, \sim 20 \mathrm{nM})$ and phosphate $\left(\mathrm{PO}_{4}, \sim 15 \mathrm{nM}\right)$ from summer to winter in the western subtropical North Pacific. Molar ratios of upward fluxes of DIC:N+N: $\mathrm{PO}_{4}$ to the euphotic zone $(<100 \mathrm{~m})$ were in near-stoichiometric balance with microbial C:N:P ratios (107 243:16 35:1). Comparison of these upward influxes with other atmospheric and marine sources demonstrated that total supply is largely driven by the other sources for $\mathrm{C}$ and $\mathrm{N}(93 \sim 96 \%)$, but not for $\mathrm{P}(10 \%)$, suggesting that nanomolar upward supply of $\mathrm{P}$ and its preferential recycling play a vital role in sustaining the NCP.

\footnotetext{
${ }^{1}$ Department of Ocean Sciences, Tokyo University of Marine Science and Technology, Tokyo, Japan. ${ }^{2}$ Institute for Marine and Antarctic Studies, University of Tasmania, Hobart, Australia. ${ }^{3}$ Atmosphere and Ocean Research Institute, The University of Tokyo, Chiba, Japan. ${ }^{4}$ Department of Aquatic Bioscience, Graduate School of Agricultural and Life Sciences, The University of Tokyo, Tokyo, Japan. ${ }^{5}$ Graduate School of Fisheries and Environmental Sciences, Nagasaki University, Nagasaki, Japan. ${ }^{6}$ Atmosphere and Ocean Department, Japan Meteorological Agency, Tokyo, Japan. ${ }^{7}$ Graduate School of Science and Engineering, Soka University, Tokyo, Japan. ${ }^{8}$ Meteorological Research Institute, Japan Meteorological Agency, Ibaraki, Japan. ${ }^{凶}$ email: f-hashi@kaiyodai.ac.jp
} 
$\mathrm{n}$ the pelagic realm of the subtropical ocean, macronutrient concentrations are chronically low ${ }^{1-3}$ and frequently below the detection limits of conventional analyses for nitrate plus nitrite $(\mathrm{N}+\mathrm{N}, 50 \mathrm{nM})$ and phosphate $\left(\mathrm{PO}_{4}, 30 \mathrm{nM}\right)^{4}$. Despite such severe oligotrophic regimes, net community production (NCP) is modestly autotrophic $^{5}$, and annual NCP in the euphotic zone of the subtropical regions $\left(15 \sim 30^{\circ} \mathrm{N} / \mathrm{S}\right)$, which was estimated by a variety of methods, ranged from 1.0 to $3.3 \mathrm{~mol} \mathrm{C} \mathrm{m}^{-2} \mathrm{y}^{-16}$. Although the NCP requires corresponding amounts of macronutrient supply from below the euphotic zone, no evidence has been found for the substantial supply of macronutrients into the euphotic zone $e^{7,8}$. Based on a calculation using microbial C:N (6 11) and C:P ratios (107 243) of Prochlorococcus, Synechococcus, and pico- and nanosized eukaryotes collected from subtropical waters ${ }^{9,10}$, macronutrient supply of $9.1 \times 10^{-2} \sim 5.5 \times 10^{-1} \mathrm{~mol} \mathrm{~N} \mathrm{~m}^{-2} \mathrm{y}^{-1}$ and $4.1 \times$ $10^{-3} \sim 3.1 \times 10^{-2} \mathrm{~mol} \mathrm{P} \mathrm{m}^{-2} \mathrm{y}^{-1}$ is required to support the estimated range of NCP $\left(1.0 \sim 3.3 \mathrm{~mol} \mathrm{C} \mathrm{m}^{-2} \mathrm{y}^{-1}\right)^{6}$. In the central subtropical North Pacific, the seasonal drawdown of the integrated nitrate stocks in the upper $250 \mathrm{~m}$ was stoichiometrically reconciled with the annual $\mathrm{NCP}^{8}$. However, there are issues with the calculation since nitrate drawdown occurred below the euphotic zone $(>100 \mathrm{~m}$ ), whereas the majority of NCP occurred in the surface mixed layer shallower than 100-m depth.

Here, we revisit the previously reported imbalance between macronutrient supply and NCP demands in the euphotic zone, using data of sensitive technique-derived nanomolar macronutrient concentrations and their vertical fluxes collected from the western subtropical North Pacific. Given that marine $\mathrm{N}_{2}$ fixation and atmospheric $\mathrm{N}$ and $\mathrm{P}$ depositions represent additional $\mathrm{N}$ and $\mathrm{P}$ sources to the euphotic zone $\mathrm{e}^{11-13}$, we summarize the annual budgets of $\mathrm{N}$ and $\mathrm{P}$ along with $\mathrm{C}$ (vertical DIC influx plus atmospheric $\mathrm{CO}_{2}$ influx) to quantify $\mathrm{C}, \mathrm{N}$, and $\mathrm{P}$ stoichiometric requirements need to support annual NCP. Our budgetary analyses conclude that annual $\mathrm{P}$ supply is stoichiometrically deficient compared to those of $\mathrm{C}$ and $\mathrm{N}$ and thus the annual NCP must be ultimately sustained by preferential recycling of $\mathrm{P}$ through microbially mediated metabolic processes ${ }^{14-19}$.

\section{Results and discussion}

Seasonal drawdown of inorganic C, N, and P. We conducted shipboard time-series measurements of physical and biogeochemical variables at five stations along a $24^{\circ} \mathrm{N}$ zonal transect $\left(133.0 \sim 140.3^{\circ} \mathrm{E}\right)$ between April 2014 and May 2019 (Fig. 1 and Supplementary Table 1). These stations are $>500 \mathrm{~km}$ away from the Japanese archipelago, Kuroshio, and North Equatorial Current, and characterized by severe depletion of surface $\mathrm{PO}_{4}(<30 \mathrm{nM})$ along with $\mathrm{N}+\mathrm{N}(<50 \mathrm{nM})^{20,21}$. Potential temperature-salinity (T-S) diagram at these stations over the study period showed no distinct east-west trend in physical properties of water masses (Supplementary Fig. 1) as potential temperature and salinity at 10-, 100-, and 200-m depths were not significantly different among the stations $(P>0.05)$. The concentrations of DIC, $\mathrm{N}+\mathrm{N}$, and $\mathrm{PO}_{4}$ were each normalized using a mean salinity (34.91) to take into account the effects of evaporation and precipitation on dissolved constituents ${ }^{22}$ in the upper $200 \mathrm{~m}$ of the study region (Fig. 2a). These normalized concentrations ( $\mathrm{nDIC}, \mathrm{nN}+\mathrm{N}$, and $\mathrm{nPO}_{4}$ ) were plotted against sea surface temperature (SST) at $10-\mathrm{m}$ depth, which showed a clear seasonal trend from $20.21^{\circ} \mathrm{C}$ in January to $30.51{ }^{\circ} \mathrm{C}$ in July, covering the range of the monthly mean SST derived from satellite observation during the study period (Supplementary Fig. $2 a, b)$. The $n D I C, n N+N$, and $n P_{4}$ generally increased with depth but exhibited trends of decreasing concentrations from the low-SST regime to the high-SST regime (Fig. 2a). Interestingly, $\mathrm{nN}+\mathrm{N}$ and $\mathrm{nPO}_{4}$ in the upper $100 \mathrm{~m}$ exhibited variability in the

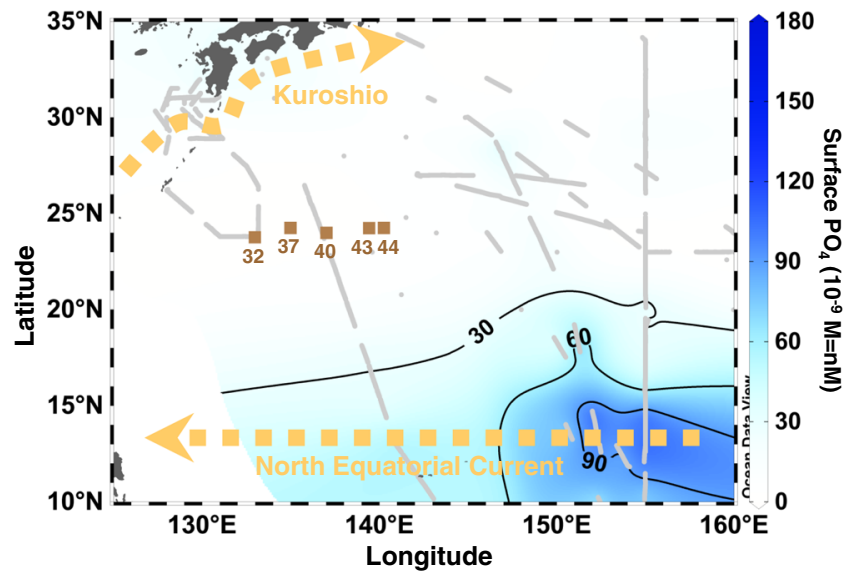

Fig. 1 Study areas and sampling stations. Stations are indicated by the brown squares. Typical flow paths of Kuroshio and North Equatorial Current are depicted by the yellow dashed arrows. The background contour shows surface $(<10 \mathrm{~m})$ nanomolar phosphate $\left(\mathrm{PO}_{4}\right)$ concentrations reported in our previous studies 20,21 . The gray dots and gray lines denote sampling stations and underway continuous sampling tracks for the nanomolar $\mathrm{PO}_{4}$, respectively.

nanomolar range $(\sim 30 \mathrm{nM})$ with lower concentrations in the stratified period characterized by the high SST $\left(>28^{\circ} \mathrm{C}\right)$ and shallow surface mixed layer depth (MLD, <50 m).

In the surface layer above $100-\mathrm{m}$ depth which corresponds to the winter MLD and mean euphotic zone depth (EZD) (Fig. 2a and Supplementary Fig. $2 \mathrm{c}, \mathrm{d})$, inventories of $\mathrm{nDIC}, \mathrm{nN}+\mathrm{N}$, and $\mathrm{nPO}_{4}$ were significantly lower in the warmer $\left(\mathrm{SST}>28^{\circ} \mathrm{C}\right)$ regime than the cooler $\left(\mathrm{SST}<24^{\circ} \mathrm{C}\right)$ regime $(P<0.05)$ (Fig. 2b). The differences between the $0 \sim 100 \mathrm{~m}$ inventories of the cooler and warmer regimes (i.e., winter-summer differences) were 1.9, $5.3 \times$ $10^{-3}$, and $6.8 \times 10^{-4} \mathrm{~mol} \mathrm{~m}{ }^{-2}$ for $\mathrm{nDIC}, \mathrm{nN}+\mathrm{N}$, and $\mathrm{nPO}_{4}$, respectively. The seasonal drawdown of nDIC from winter to summer $\left(1.9 \pm 0.8 \mathrm{~mol} \mathrm{~m}^{-2}\right)$, which typically contributes a substantial proportion of annual $\mathrm{NCP}^{23,24}$, was within the bounds of previous estimates of annual NCP in the subtropical oceans $\left(1.0 \sim 3.3 \mathrm{~mol} \mathrm{C} \mathrm{m}^{-2} \mathrm{y}^{-1}\right)^{6}$. In the layer between 100 and $200 \mathrm{~m}$, the inventories of nDIC were not significantly different between any pair of SST regimes $(P>0.05)$, while those of $\mathrm{nN}+\mathrm{N}$ and $\mathrm{nPO}_{4}$ were significantly lower in the regime of SST $>28^{\circ} \mathrm{C}$ than that of SST $<24^{\circ} \mathrm{C}(P<0.05)$, suggesting that seasonal drawdown of macronutrients in the $100 \sim 200 \mathrm{~m}$ layer was not linked to the NCP.

Upward fluxes of inorganic $\mathbf{C}, \mathbf{N}$, and $\mathbf{P}$. We estimated vertical fluxes of DIC, $\mathrm{N}+\mathrm{N}$, and $\mathrm{PO}_{4}$ in the upper $200 \mathrm{~m}$ of the study region between June 2016 and May 2019 (Fig. 3a and Supplementary Table 1), using the vertical concentration gradients of DIC, $\mathrm{N}+\mathrm{N}$, and $\mathrm{PO}_{4}$ and the vertical diffusivity $\left(K_{z}\right)$ determined using fast-response thermistors ("Methods"). Here, we regarded the mean fluxes in the MLD 100 $\mathrm{m}$ and 100 200 m layers as upward fluxes into the mixed layer and euphotic zone, respectively (Fig. 3b), based on the theory proposed by previous macronutrient flux studies ${ }^{25-27}$. The DIC, $\mathrm{N}+\mathrm{N}$, and $\mathrm{PO}_{4}$ upward fluxes generally showed positive values even in the MLD 100 m layer, and were higher in SST regimes of $<28^{\circ} \mathrm{C}$ than the $>28^{\circ} \mathrm{C}$ regime, particularly for $\mathrm{N}+\mathrm{N}$ and $\mathrm{PO}_{4}$ fluxes. The positive upward fluxes of $\mathrm{N}+\mathrm{N}$ and $\mathrm{PO}_{4}$ in the MLD 100 m layer were ascribed to the nanomolar concentration gradients of $\mathrm{N}+\mathrm{N}$ and $\mathrm{PO}_{4}$ (Supplementary Fig. 3). Historically, it had been reported that there is no upward nitrate supply to the mixed layer of the subtropical North Pacific due to the lack of a vertical 

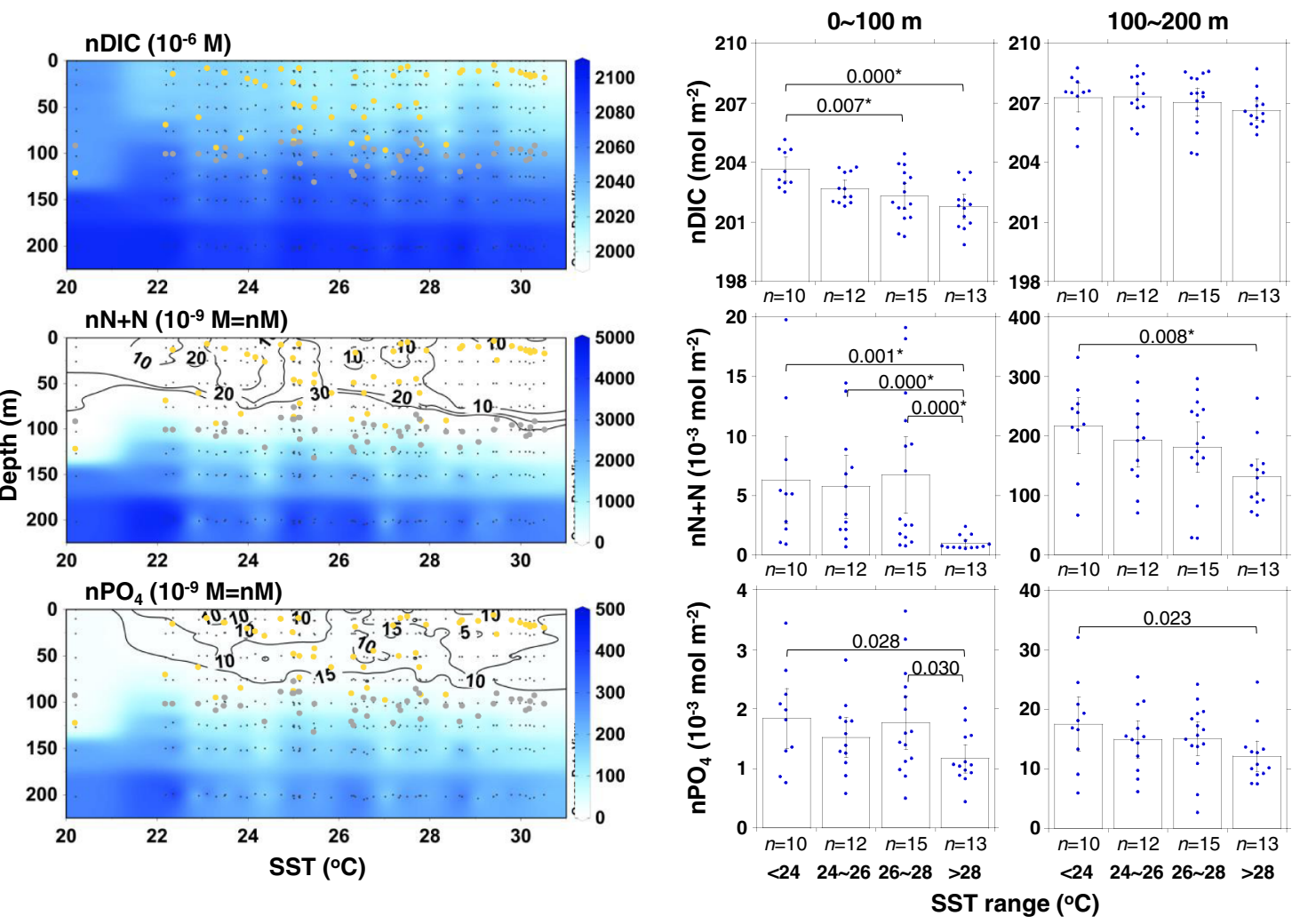

Fig. 2 Distribution of the salinity (39.41) normalized dissolved inorganic carbon (nDIC), nitrate plus nitrite $(\mathrm{nN}+\mathrm{N})$, and phosphate $\left(\mathrm{nPO} \mathrm{O}_{4}\right)$ over sea surface temperature (SST) in the upper $\mathbf{2 0 0} \mathbf{m}$ of the western subtropical North Pacific. a Vertical distributions of $n D I C, n N+N$, and $n P O_{4}$ concentrations plotted against SST. The small black dots denote the sampling depths. The yellow and gray solid circles indicate the mixed layer depth (MLD) and euphotic zone depth (EZD), respectively. The black contour lines in the $\mathrm{nN}+\mathrm{N}$ and $\mathrm{nPO}$, panels represent nanomolar gradients of $\sim 30 \mathrm{nM}$ (10 $\mathrm{nM}$ interval) and $\sim 15 \mathrm{nM}\left(5 \mathrm{nM}\right.$ interval), respectively. $\mathbf{b}$ Integrated stocks of $\mathrm{nDIC}, \mathrm{nN}+\mathrm{N}$, and $\mathrm{nPO}_{4}$ in four different SST regimes within the $0 \sim 100 \mathrm{~m}$ (left) and 100 $200 \mathrm{~m}$ (right) layers. Bar charts represent mean values of the integrated stocks indicated as blue dots. The error bars denote the $95 \%$ confidence interval $(\mathrm{Cl})$. Significant differences (two-sided Kruskal-Wallis test, $P<0.05$ ) in the mean stocks between the SST regimes are depicted just above the bars. Significant differences of multiple comparisons with the Dunn's procedure after the Kruskal-Wallis test $(P<0.0083)$ are marked with an asterisk $\left({ }^{\star}\right)$.

concentration gradient in nitrate in the euphotic zone ${ }^{28,29}$. However, our observations revealed that $\mathrm{N}+\mathrm{N}$ and $\mathrm{PO}_{4}$ were supplied to the mixed layer particularly in the cool period with SST $<28^{\circ} \mathrm{C}$, and thus potentially support the NCP.

We present several additional lines of evidence for seasonal linkages between upward macronutrient supply and microbial dynamics. We found that the increases in upward macronutrient fluxes into the euphotic zone from summer (SST $>28^{\circ} \mathrm{C}$ ) to winter (SST $<24^{\circ} \mathrm{C}$ ) (Fig. 3) likely explain the corresponding increases in inventories of total particulate $\mathrm{P}$ (TPP) in the 0 100 m layer from summer to winter (Supplementary Fig. 4a, b). Since TPP is a useful metric for living microbial biomass ${ }^{3,9}$, these seasonal trends suggest that the enhanced upward macronutrient supply induced an increase in microbial biomass. In addition, the chemical composition of TPP showed that, although nucleic acid $\mathrm{P}$ was a major component of TPP over the study period, the proportion of orthophosphate $\left(\mathrm{PO}_{4}\right)$ in TPP was significantly higher in the cool period $\left(24^{\circ} \mathrm{C}<\mathrm{SST}<26^{\circ} \mathrm{C}\right)$ than in the warm period (SST $>28^{\circ} \mathrm{C}$ ) (Supplementary Fig. $4 \mathrm{c}$, d); this finding is evidence for constant microbial uptake (or adsorption onto the cell surface ${ }^{30}$ and accumulation in the periplasm ${ }^{31}$ ) of $\mathrm{PO}_{4}$ that was supplied upward from the subsurface layer below $100 \mathrm{~m}$ over the cool period. We also found a seasonal succession of major microbial groups in the upper $100 \mathrm{~m}$ of the study region from pico- and nano-sized eukaryotes in winter to cyanobacteria
(Prochlorococcus and Synechococcus) in summer and vice versa (Supplementary Fig. 5). Since the microbial C biomass is largely contributed by cyanobacteria in low-macronutrient oligotrophic regimes $^{9,10}$, the higher proportion of $\mathrm{C}$ biomass of cyanobacteria relative to eukaryotes in summer than winter was likely associated with the lower upward fluxes of macronutrients in summer than winter (Fig. 3).

Magnitude of NCP is driven by rapid $P$ recycling. The annual NCP in the subtropical ocean is balanced by annual downward fluxes of particulate and dissolved organic $\mathrm{C}$ including those through zooplankton migration, indicating that net $\mathrm{C}$ uptake and downward export are at a steady state over the annual cycle ${ }^{6,32}$. Assuming the steady state at the annual scale, we estimated C, N, and $\mathrm{P}$ requirements for the annual NCP (NCP-C, $-\mathrm{N}$, and $-\mathrm{P}$ ) in the $0 \sim 100 \mathrm{~m}$ layer (Fig. 4), using total annual influxes of $\mathrm{C}, \mathrm{N}$, and $\mathrm{P}$ that include upward fluxes of DIC, $\mathrm{N}+\mathrm{N}$, and $\mathrm{PO}_{4}$ from the subsurface layer $(100 \sim 200 \mathrm{~m})$ based on in situ observation (Fig. 3b), atmospheric $\mathrm{CO}_{2}$ flux and $\mathrm{N}$ and $\mathrm{P}$ depositions, and marine $\mathrm{N}_{2}$ fixation (Supplementary Fig. 6 and "Methods"). The NCP-C, $-\mathrm{N}$, and -P were $7.5 \times 10^{-1}, 9.5 \times 10^{-2}$, and $3.2 \times 10^{-4}$ mol m${ }^{-2} \mathrm{y}^{-1}$, respectively. The NCP-C $\left(7.5 \times 10^{-1} \pm 1.5 \times 10^{-1}\right.$ mol m $\left.\mathrm{m}^{-2} \mathrm{y}^{-1}\right)$ is comparable to the lowest estimates of previous studies in the subtropical oceans $\left(1.0 \sim 3.3 \mathrm{~mol} \mathrm{C} \mathrm{m}^{-2} \mathrm{y}^{-1}\right)^{6}$. This low estimate may be due to the noninclusion of upward supply of 

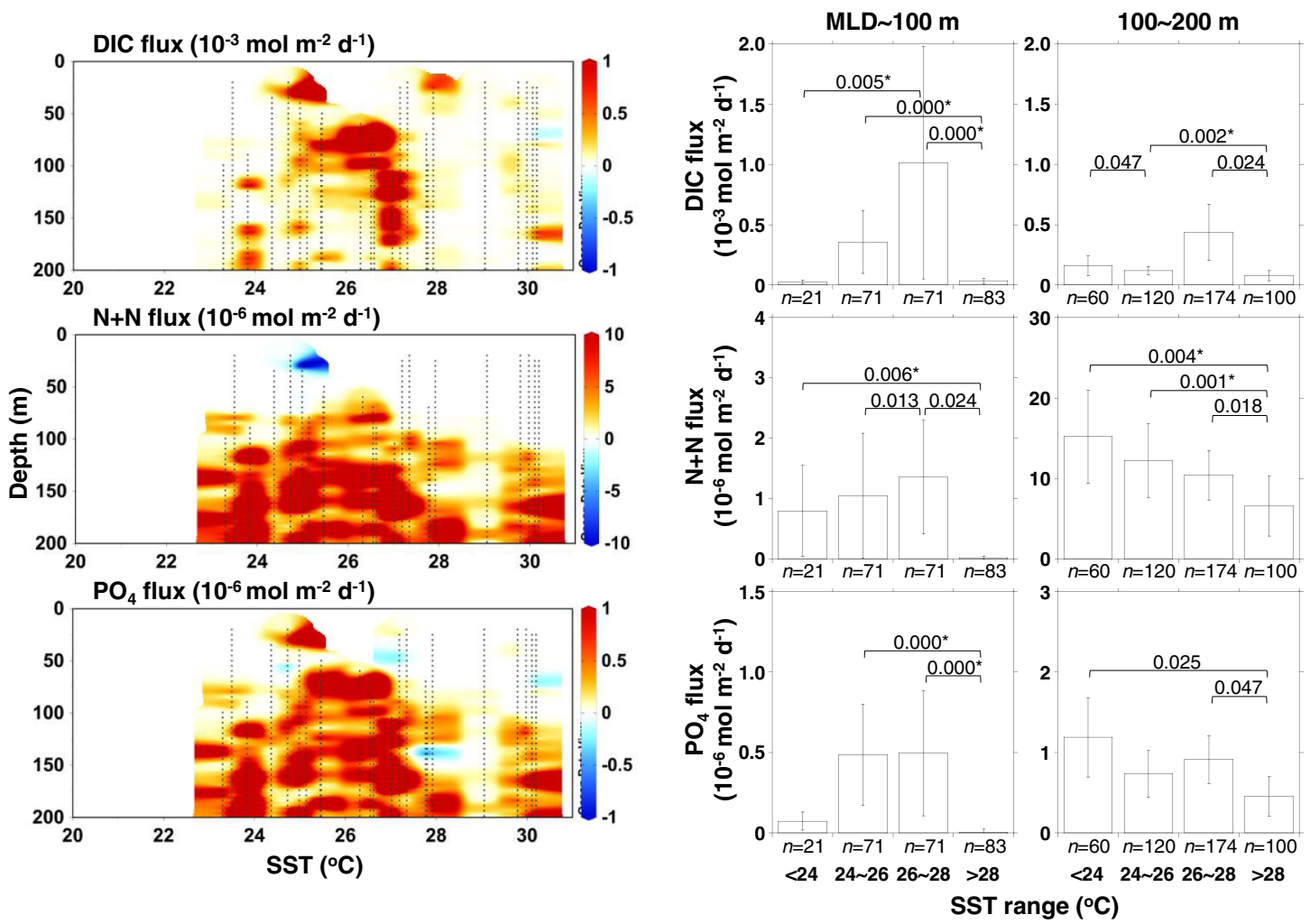

Fig. 3 Vertical fluxes of dissolved inorganic carbon (DIC), nitrate plus nitrite $(\mathrm{N}+\mathrm{N})$, and phosphate $\left(\mathrm{PO}_{4}\right)$ over sea surface temperature (SST) in the layer between the mixed layer depth (MLD) and 200-m depth of the western subtropical North Pacific. a Vertical profiles of DIC, $\mathrm{N}+\mathrm{N}$, and $\mathrm{PO}{ }_{4}$ fluxes plotted against SST. The small black dots denote the depths where $K_{z}$ data were obtained. b Mean fluxes of DIC, N+N, and PO 4 in four different SST regimes within the MLD 100 $\mathrm{m}$ (left) and 100 200 m (right) layers shown in a. The error bars denote the 95\% confidence interval (CI). Significant differences (two-sided Kruskal-Wallis test, $P<0.05$ ) in the mean fluxes between the SST regimes are stated just above the bars. Significant differences of multiple comparisons with the Dunn's procedure after the Kruskal-Wallis test $(P<0.0083)$ are marked with an asterisk $\left(^{\star}\right)$.

DIC during the cool period with SST $<23{ }^{\circ} \mathrm{C}$ (Fig. 3) and/or the passage of typhoon and eddies ${ }^{33}$ when shipboard observation could not be performed. The missing DIC supply is also inferred from the lower value of NCP-C $\left(7.5 \times 10^{-1} \pm 1.5 \times 10^{-1} \mathrm{~mol} \mathrm{~m}^{-2}\right.$ $\mathrm{y}^{-1}$ ) than the seasonal drawdown of nDIC from winter to summer $\left(1.9 \pm 0.8 \mathrm{~mol} \mathrm{~m}^{-2}\right.$, Fig. $\left.2 \mathrm{~b}\right)$.

Interestingly, the stoichiometric ratio of the annual NCP-C, $-\mathrm{N}$, and -P (2364:299:1) (Fig. 4) was higher than the C:N:P ratio of subtropical microbes (107 243:16 35:1 $)^{9,10}$, indicating that the $\mathrm{P}$ influx was (stoichiometrically) lower than the $\mathrm{C}$ and $\mathrm{N}$ influxes. Regarding the annual upward flux, the ratios of DIC:N+N:PO $(182: 14: 1)$ were in near-stoichiometric balance to the C:N:P ratio of subtropical microbes compared to that of annual NCP. In addition, there were substantial annual influxes of $\mathrm{C}$ and $\mathrm{N}$ from the atmosphere and marine $\mathrm{N}_{2}$ fixation. The contribution of marine $\mathrm{N}_{2}$ fixation reached $85 \%$ in the NCP-N. This is in line with recent findings at the Hawaii Ocean Time-Series (HOT) in the subtropical North Pacific that the annual rate of marine $\mathrm{N}_{2}$ fixation is stoichiometrically reconciled with the annual $\mathrm{NCP}^{34}$. Meanwhile, the annual $\mathrm{P}$ influx from the atmosphere was almost negligible and the upward marine $\mathrm{P}$ influx accounted for $90 \%$ of the total P influx. When only considering inorganic C-N-P forms, the total influx of $\mathrm{P}$ thus did not meet microbial $\mathrm{P}$ demand.

As an alternative to $\mathrm{PO}_{4}$, dissolved organic phosphorus (DOP) is an important $\mathrm{P}$ source for the microbes in the western subtropical North Pacific ${ }^{3,35}$. However, a significant seasonal change in the salinity (34.91) normalized DOP inventory (nDOP) was not observed in the $0 \sim 100 \mathrm{~m}$ layer from the cooler $\left(\mathrm{SST}<24^{\circ} \mathrm{C}\right.$ ) regime to warmer $\left(\mathrm{SST}>28^{\circ} \mathrm{C}\right.$ ) regime (Supplementary Fig. 7a, b). Furthermore, the vertical DOP flux was smaller than the vertical $\mathrm{PO}_{4}$ flux due to its small concentration gradient, and the annual vertical DOP flux was not significantly different from zero in both the MLD 100 m $\left(4.8 \times 10^{-6} \pm 2.6 \times 10^{-5} \mathrm{~mol} \mathrm{~m}^{-2} \mathrm{y}^{-1}\right)$ and $100 \sim 200 \mathrm{~m}\left(-2.4 \times 10^{-5} \pm 3.0 \times 10^{-5} \mathrm{~mol} \mathrm{~m}^{-2} \mathrm{y}^{-1}\right)$ layers (Supplementary Figs. 3 and $7 \mathrm{c}, \mathrm{d}$ ). Several studies reported the importance of lateral DOP supply into the subtropical gyres from the gyre margins ${ }^{36,37}$. However, the lateral supply of DOP along with $\mathrm{PO}_{4}$ into the study area was negligible, because the compiled data on our previous studies 3,38 and this study demonstrated that inventories of total dissolved $\mathrm{P}\left(\mathrm{TDP}=\mathrm{DOP}+\mathrm{PO}_{4}\right)$ in the $0 \sim 100 \mathrm{~m}$ layer of the $24^{\circ} \mathrm{N}$ zonal transect were not significantly different from those of $20 \sim 24^{\circ} \mathrm{N}$ and $24 \sim 30^{\circ} \mathrm{N}$ in the western subtropical North Pacific $(P>0.05$, Supplementary Fig. 8). Since the DOP supply and its microbial demand are spatiotemporally balanced, nanomolar vertical $\mathrm{PO}_{4}$ supply to the euphotic zone and rapid internal recycling of $P$, relative to $C$ and $N$, within the euphotic zone are suggested to be major processes driving the NCP. This perspective is also supported by a range of biogeochemical studies which showed that organic $\mathrm{P}$ is preferentially remineralized compared to organic $\mathrm{N}$ and $\mathrm{C}$ (i.e., the shorter turnover time of organic $\mathrm{P}$ than organic $\mathrm{N}$ and $\mathrm{C}$ ) in the various subtropical regions of the global ocean ${ }^{14-19}$.

Our datasets on nanomolar concentrations of $\mathrm{N}+\mathrm{N}$ and $\mathrm{PO}_{4}$ make their upward supply to not only the euphotic zone but also the 


\section{Carbon}

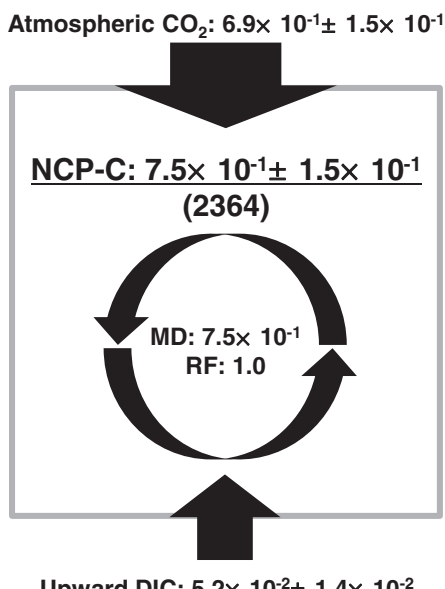

(182)
Nitrogen

$\mathrm{N}_{2}$ fixation: $8.1 \times 10^{-2} \pm 1.3 \times 10^{-2}$

Atmospheric N: $1.0 \times 10^{-2} \pm 1.2 \times 10^{-3}$

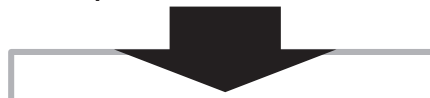

NCP-N: $9.5 \times 10^{-2} \pm 1.3 \times 10^{-2}$ (299)

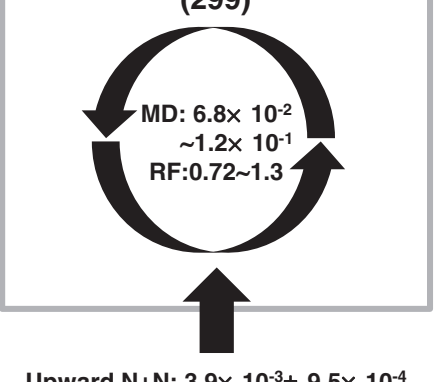

(14)
Phosphorus

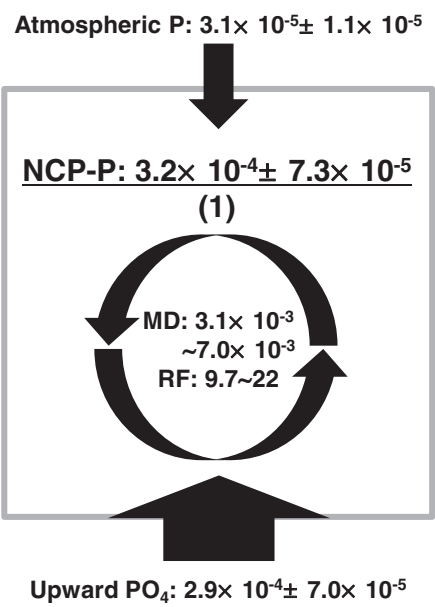

(1)

Fig. 4 The $\mathbf{C}, \mathbf{N}$, and $\mathbf{P}$ requirements for annual net community production (NCP). Each box represents the water column ( $0 \sim 100 \mathrm{~m}$ depth). The upward and downward black arrows with black text indicate the influxes (mol $\mathrm{m}^{-2} \mathrm{y}^{-1}$ ) from the subsurface layer (100 200-m depth) and atmosphere (including marine $\mathrm{N}_{2}$ fixation), respectively. The width of the arrows indicates the relative magnitudes of influxes to the total influx for each element. The $C$, $N$, and $P$ requirements for annual NCP (mol m $\mathrm{m}^{-2} \mathrm{y}^{-1}$ ) are denoted using underlined text. Stoichiometric ratios of the NCP-C:NCP-N:NCP-P and upward dissolved inorganic carbon (DIC):nitrate plus nitrite $(\mathrm{N}+\mathrm{N})$ :phosphate $\left(\mathrm{PO}_{4}\right)$ are denoted in parentheses. The microbial demands based on the $\mathrm{C}: \mathrm{N}$ : $\mathrm{P}$ ratio of subtropical microbes $9,10\left(\mathrm{MD}, \mathrm{mol} \mathrm{m} \mathrm{m}^{-2} \mathrm{y}^{-1}\right)$ and the recycling factors ( $\mathrm{RF}=\mathrm{MD} / \mathrm{NCP}$, no unit) are represented within the circle of arrows. The errors of the stated values denote the $95 \%$ confidence interval $(\mathrm{Cl})$. The procedures for calculating the stated values are described in the main text and "Methods".

mixed layer conspicuous; however, it is currently problematic to measure the recycling rates (i.e., uptake or regeneration rates at a steady state) of $\mathrm{N}$ and $\mathrm{P}$ using the conventional stable or radioisotopic methods 39,40 which have some issues with bottle effects, filtration effects, and incubation time as well known in the primary production estimates using ${ }^{13} \mathrm{C}$ and ${ }^{14} \mathrm{C}^{41}$. Hence in our study, we must constrain to assess the recycling of $\mathrm{N}$ and $\mathrm{P}$ by comparing microbial demand (MD) with NCP-N and -P. Assuming that the C:N (6 11) and C:P (107 243) ratios of subtropical microbes ${ }^{9,10}$ are representatives of $\mathrm{MD}$ ratios, the annual MD-N and - $\mathrm{P}$ are estimated to be $6.8 \times 10^{-2} \sim 1.2 \times 10^{-1} \mathrm{~mol} \mathrm{~N} \mathrm{~m}{ }^{-2} \mathrm{y}^{-1}$ and $3.1 \times 10^{-3} \sim 7.0 \times 10^{-3} \mathrm{~mol} \mathrm{P} \mathrm{m}^{-2} \mathrm{y}^{-1}$, respectively, based on the NCP-C $\left(7.5 \times 10^{-1} \mathrm{~mol} \mathrm{C} \mathrm{m}^{-2} \mathrm{y}^{-1}\right)$ (Fig. 4). The MD-N is comparable to the NCP-N quantified in situ $\left(9.5 \times 10^{-2} \mathrm{~mol} \mathrm{~N} \mathrm{~m}^{-2} \mathrm{y}^{-1}\right)$, while the MD-P is 9.7 22-fold higher than the NCP-P quantified in situ $\left(3.2 \times 10^{-4} \mathrm{~mol} \mathrm{P} \mathrm{m}^{-2} \mathrm{y}^{-1}\right)$. In other words, the internal recycling rate of $\mathrm{N}$ is similar to that of $\mathrm{C}$, but that of $\mathrm{P}$ is 9.7 22-fold faster than that of $\mathrm{C}$ (referred to as recycling factors (RF) in Fig. 4).

In this study, we found that nanomolar macronutrient supply contributes to the NCP in the mixed layer of the western subtropical North Pacific. Our C-N-P budgetary analysis showed that the NCP in the euphotic zone is driven by the stoichiometrically $\mathrm{P}$-deficient $\mathrm{C}-\mathrm{N}-\mathrm{P}$ influx. As a range of biogeochemical studies suggested preferential remineralization of organic $\mathrm{P}$ relative to organic $\mathrm{C}$ and $\mathrm{N}^{14-19}$, the rapid internal recycling of $\mathrm{P}$ in the euphotic zone could play a vital role in sustaining the NCP in the oligotrophic subtropical ocean. Since marine $\mathrm{N}_{2}$ fixation and atmospheric $\mathrm{N}$ deposition are projected to increase with ocean warming ${ }^{42}$ and anthropogenic activities ${ }^{12,43}$, respectively, the $\mathrm{P}$ supply and recycling would become more influential in controlling the NCP in the subtropical ocean in the coming decades.

\section{Methods}

Observations and sampling. Time-series observations in the western subtropical North Pacific were conducted aboard the R/V Keifu-maru and R/V Ryofu-maru of
Japan Meteorological Agency (JMA). We occupied five stations along a $24^{\circ} \mathrm{N}$ zonal transect from $133.0^{\circ} \mathrm{E}$ to $140.3^{\circ} \mathrm{E}$ during 13 cruises between April 2014 and May 2019 (Fig. 1 and Supplementary Table 1). Every cruise generally occupied Stations $32,37,40$, and 44 , but the observations were not conducted at Station 44 of the KS15-01cruise and at Stations 37 and 44 of the KS16-01cruise. During the KS1601cruise, Station 43 was occupied instead of Station 44.

At all stations, water samples were collected from 9 depths $(0,10,25,50,75$, $100,125,150$, and $200 \mathrm{~m}$ ) in the upper $200 \mathrm{~m}$ of the water column using an acidcleaned bucket (for surface layer) and 12-L acid-cleaned Niskin bottles (General Oceanics) mounted on a conductivity-temperature-depth (CTD) system (Sea-Bird Electronics). MLD was determined using the temperature profile obtained by the $\mathrm{CTD}$ sensor, as the depth where the potential temperature was $0.2^{\circ} \mathrm{C}$ less than that at 10 -m depth ${ }^{44}$. Vertical profiles of photosynthetically active radiation (PAR) were measured using a DEFI2-L PAR sensor (JFE Advantech) to determine EZD, defied as the depth of $1 \%$ PAR relative to surface $\mathrm{PAR}^{45}$. The PAR observations were conducted at most stations, but when the station was occupied during nighttime, PAR was measured in the daytime at a nearby site (within $132 \mathrm{~km}$ ). To confirm the seasonal trend of SST in the study region, we used data on monthly mean satellite SST (MODIS Aqua Level 3 SST MID-IR Monthly $4 \mathrm{~km}$ Nighttime V2019.0) ${ }^{46}$ within the area between $23.5 \sim 24.5^{\circ} \mathrm{N}$ and $132.5 \sim 140.5^{\circ} \mathrm{E}$ for the period from April 2014 to May 2019.

Determination of dissolved constituents. Water samples for DIC, $\mathrm{N}+\mathrm{N}, \mathrm{PO}_{4}$, and DOP were taken throughout the study period (Supplementary Table 1). Subsamples for DIC analyses were collected into $250-\mathrm{mL}$ borosilicate glass bottles with ground glass stoppers lubricated with Apiezon L grease. They were poisoned with mercury (II) chloride and analyzed by a $\mathrm{CO}_{2}$ extraction-coulometry method using a DIC analyzer manufactured by Nippon ANS. To establish the identical concentration scale across the cruises, we used numbers of batches of Certified Reference Material for DIC and total alkalinity analyses provided by A.G. Dickson at the University of California, San Diego ${ }^{47}$. The precision of DIC analysis was $2.0 \times 10^{-6} \pm 3.4 \times 10^{-6} \mathrm{M}(n=194)$.

Water samples for $\mathrm{N}+\mathrm{N}$ and $\mathrm{PO}_{4}$ were collected in 30-mL polypropylene tubes for nanomolar $\left(10^{-9} \mathrm{M}=\mathrm{nM}\right)$ level analysis and in $10-\mathrm{mL}$ polymethylpentene tubes for micromolar $\left(10^{-6} \mathrm{M}\right)$ level analysis. The samples for the nanomolar level analysis were frozen and stored at $-20^{\circ} \mathrm{C}$ until the analyses were conducted onshore, and those for micromolar level analysis were immediately processed onboard. The nanomolar levels of $\mathrm{N}+\mathrm{N}$ and $\mathrm{PO}_{4}(<1000 \mathrm{nM})$ were determined using an automated liquid waveguide spectrophotometric system equipped with $50-$ and $100-\mathrm{cm}$ liquid waveguide capillary cells (LWCC, World Precision Instruments), respectively ${ }^{2}$. The detection limits for nitrate, nitrite, and $\mathrm{PO}_{4}$ were 3 , 2 , and $3 \mathrm{nM}$, respectively ${ }^{48}$. The reproducibility of nitrate, nitrite, and $\mathrm{PO}_{4}$ at $100 \mathrm{nM}$ had a coefficient of variation $(\mathrm{CV})$ of $2 \%(n=10)^{48}$. In the calculation of vertical fluxes, water column integrated stocks, stoichiometric molar ratio, and DOP concentration (see below), the $\mathrm{N}+\mathrm{N}$ and $\mathrm{PO}_{4}$ concentrations below the 
detection limits ( $11 \%$ and $9 \%$ of all data, respectively) were regarded as 5 and $3 \mathrm{nM}$, respectively. The micromolar concentrations $(>1000 \mathrm{nM})$ of $\mathrm{N}+\mathrm{N}$ were determined using a conventional autoanalyzer (SEAL Analytical).

DOP water samples were collected in 30-mL polypropylene tubes after removing particulate matter by filtering through precombusted Whatman GF/F filters. The samples were frozen and stored at $-20^{\circ} \mathrm{C}$ until the analyses were performed onshore. DOP concentrations were determined by a sensitive method ${ }^{35}$ TDP was quantified by liquid waveguide spectrophotometry for $\mathrm{PO}_{4}{ }^{2}$ after the filtrate sample was oxidized with acid persulfate ${ }^{49}$. The oxidation efficiency of $100 \mathrm{nM}$ organic P analogs (D-Glucose-6-phosphate sodium salt, Sodium tripolyphosphate pentabasic, and Sodium phosphonoformate tribasic hexahydrate from Sigma-Aldrich) was $98 \sim 104 \%$ and the CV of the measurements was $1 \%$ $(n=9)$. DOP concentrations were derived from the difference between TDP and $\mathrm{PO}_{4}$ concentrations.

Estimating vertical fluxes of dissolved constituents. We estimated the vertical fluxes of DIC, $\mathrm{N}+\mathrm{N}, \mathrm{PO}_{4}$, and DOP in the layer between the MLD and 200-m depth during the six cruises between June 2016 and May 2019, since data on vertical diffusivity $\left(K_{z}\right)$ were available for this period (Supplementary Table 1). We excluded the upward and downward fluxes of DIC, $\mathrm{N}+\mathrm{N}$, and $\mathrm{PO}_{4}$ within the mixed layer from our analyses because these are not influxes from outside the mixed layer and do not support the NCP in the mixed layer at a steady state. To calculate the vertical fluxes, we used the following equation:

$$
F_{X}=K_{z}(\partial X / \partial z)
$$

where $F$ is the vertical flux, $X$ is the dissolved constituents (DIC, N+N, $\mathrm{PO}_{4}$, or DOP), and $\partial X / \partial z\left(\mathrm{~mol} \mathrm{~m}^{-4}\right)$ is the vertical gradient of the dissolved constituents. The $K_{z}\left(\mathrm{~cm}^{2} \mathrm{~s}^{-1}\right)$ was estimated using CTD-attached fast-response thermistors (AFPO7; Rockland Scientific International Company) ${ }^{50-53}$, and was calculated using the following equation:

$$
K_{z}=0.2 \varepsilon N^{-2}
$$

where $\varepsilon\left(\mathrm{W} \mathrm{kg}^{-1}\right)$ is turbulent kinetic energy dissipation rate and $N\left(\mathrm{~s}^{-1}\right)$ is buoyancy frequency. As $X$ flux was obtained from the $5-\mathrm{m}$ interval $K_{z}$ data, we also used the $5-\mathrm{m}$ interval $\partial X / \partial z$ data which was derived from the linearly interpolated concentrations of $X$ between sampling depths (Supplementary Fig. 3).

Determination of particulate $\mathbf{P}$ and its chemical composition. Water samples for TPP were taken throughout the study period (Supplementary Table 1). Sample processing and analysis were followed by the procedure for the sensitive determination of TPP ${ }^{54}$. Water volumes of $200 \mathrm{~mL}$ were filtered through precombusted acid-washed GF/F filters. The samples were stored at $-20^{\circ} \mathrm{C}$ until onshore measurement. TPP measurements were performed by liquid waveguide spectrophotometry for $\mathrm{PO}_{4}{ }^{2}$ after a wet oxidation treatment using $3 \%$ potassium persulfate $\left(\right.$ Wako) ${ }^{55}$. The sensitive TPP measurements using ultraoligotrophic water samples had a CV of $4.3 \%(n=5)^{54}$.

Water samples for TPP composition were collected from three depths $(10,50$, and $100 \mathrm{~m}$ ) at the stations during the five cruises between June 2016 and December 2017 (Supplementary Table 1). The TPP composition was determined by a combination method of chemical fractionation ${ }^{56}$ and liquid waveguide spectrophotometry ${ }^{2,54}$. Water volumes of $2.3 \mathrm{~L}$ were filtered through precombusted acid-washed GF/F filters. The samples were stored at $-20^{\circ} \mathrm{C}$ until onshore measurement. According to the chemical fractionation procedures involving trichloroacetic acid extraction, hot dilute acid treatment, charcoal treatment, and organic solvent extraction, TPP was divided into orthophosphate, sugar P, nucleotide $\mathrm{P}$, nucleic acid $\mathrm{P}$, lipid $\mathrm{P}$, acid-soluble poly $\mathrm{P}$, acid-insoluble poly $\mathrm{P}$, and residual $\mathrm{P}^{56}$. After converting the $\mathrm{P}$ in each chemical fraction to $\mathrm{PO}_{4}$ with a wet oxidation treatment ${ }^{54,55}$, the $\mathrm{P}$ amount was determined by liquid waveguide spectrophotometry for $\mathrm{PO}_{4}{ }^{2}$. In the liquid waveguide spectrophotometric analysis, the treated individual solutions with the GF/F filter (no sample on it) were used as blank and standard matrices. The CV of the mean $\mathrm{P}$ concentration in each fraction $(n=3)$ accounted for $<10 \%$ of the TPP concentration, indicating that the proportion of each $\mathrm{P}$ fraction in TPP was reliable.

Flow cytometry for microbial analysis. Water samples for flow cytometry (FCM) were taken from the seven cruises between April 2014 and June 2016 (Supplementary Table 1). The $5-\mathrm{mL}$ samples were fixed with $1 \%(\mathrm{v} / \mathrm{v})$ glutaraldehyde. The fixed samples were frozen in liquid nitrogen and then stored at $-80^{\circ} \mathrm{C}$ until onshore analysis. We analyzed the samples using a flow cytometer (CyFlow Space, Partec $)^{57}$. Prochlorococcus, Synechococcus, and pico- and nano-sized eukaryotes were identified using the conventional protocols $s^{58}$. Gating strategy using forward light scatter, side light scatter, orange fluorescence, and red fluorescence was described in our previous studies ${ }^{57,59}$. The gating was processed with FloMax ver. 2.3 (Partec). The $\mathrm{C}$ biomass of these microbial groups was estimated by multiplying the FCM-derived cell abundance by the published cellular $\mathrm{C}$ quota. We used the cellular C quota of $5.2 \times 10^{-15}, 3.0 \times 10^{-14}$, and $3.9 \times 10^{-13} \mathrm{~mol} \mathrm{C}$ cell $^{-1}$ for Prochlorococcus, Synechococcus, and eukaryotes, respectively ${ }^{10}$. The contributions of the $\mathrm{C}$ biomass of individual groups to the total $\mathrm{C}$ biomass of these groups were compared (Supplementary Fig. 5b).
Estimating $\mathbf{C}, \mathbf{N}$, and $\mathbf{P}$ requirements need to support annual $\mathbf{N C P}$. The $\mathrm{C}, \mathrm{N}$ and $\mathrm{P}$ requirements for annual NCP in the $0 \sim 100 \mathrm{~m}$ layer of the study region were estimated assuming a steady state over the annual scale by the following equation:

$$
\mathrm{NCP}-\mathrm{Y}=\text { Fup }_{\mathrm{Y}}+\text { Fat }_{\mathrm{Y}}
$$

where $\mathrm{Y}$ is $\mathrm{C}, \mathrm{N}$ or $\mathrm{P}$. Fup $\mathrm{Fup}_{\mathrm{N}}$, and Fup $_{\mathrm{P}}$ are annual upward influxes of DIC, $\mathrm{N}+\mathrm{N}$, and $\mathrm{PO}_{4}$, respectively. Fat ${ }_{\mathrm{C}}, \mathrm{Fat}_{\mathrm{N}}$, and $\mathrm{Fat}_{\mathrm{P}}$ are annual influxes of atmospheric $\mathrm{CO}_{2}$, the sum of marine $\mathrm{N}_{2}$ fixation and atmospheric $\mathrm{N}$ deposition, and atmospheric $\mathrm{P}$ deposition, respectively. In the central part $\left(20 \sim 30^{\circ} \mathrm{N}\right)$ of the western subtropical North Pacific, lateral fluxes of $\mathrm{C}, \mathrm{N}$, and $\mathrm{P}$ are generally negligible, because no significant horizontal concentration gradients of DIC, $\mathrm{N}+\mathrm{N}$, and $\mathrm{PO}_{4}$ in the surface layer were observed previously ${ }^{3,20,21,23}$ (that of TDP was described in the main text with Supplementary Fig. 8). Nutrient transport by vertically migrating diatoms is another important source sustaining the $\mathrm{NCP}^{60,61}$. However, our microscopic observation using the Utermöhl method ${ }^{62}$ revealed that abundance of the migrating diatoms (Rhizosolenia spp.) was consistently low $(1.0 \pm 0.3$ cells $\mathrm{L}^{-1}, n=234$ ) in the upper $200 \mathrm{~m}$ of the study area during the seven cruises between April 2014 and June 2016 (Supplementary Table 1) and thus we did not include the macronutrient flux by the migrating diatoms. In the calculation of annual fluxes, the numbers of months in four different SST regimes were first determined using the monthly mean satellite SST (Supplementary Fig. 2b), and then the annual fluxes were estimated by summarizing the integrated fluxes of four different SST regimes (Supplementary Fig. 6).

The integrated upward influx of DIC, N+N, or $\mathrm{PO}_{4}$ in each SST regime to estimate Fup $_{\mathrm{C}}$, Fup $\mathrm{p}_{\mathrm{N}}$, and Fup $\mathrm{p}_{\mathrm{p}}$ was based on in situ data shown in Fig. 3b, and it was calculated by multiplying mean daily upward flux in the subsurface layer $(100 \sim 200 \mathrm{~m}$, Fig. 3b) by the numbers of days in each SST regime.

The integrated air-sea $\mathrm{CO}_{2}$ flux in each SST regime was calculated by multiplying the mean monthly air-sea $\mathrm{CO}_{2}$ flux by the numbers of months in each SST regime. The monthly air-sea $\mathrm{CO}_{2}$ fluxes from April 2014 to May 2019 within the area between $23.5 \sim 24.5^{\circ} \mathrm{N}$ and $132.5 \sim 140.5^{\circ} \mathrm{E}$ were estimated using the $p \mathrm{CO}_{2}$ diagnostic model ${ }^{63}$. The ocean of the study region acted as $\mathrm{CO}_{2}$ sink through most periods except for the SST $>28^{\circ} \mathrm{C}$ regime (Supplementary Fig. 6), and totally Fat showed a positive value (Fig. 4).

The annual flux of marine $\mathrm{N}_{2}$ fixation was estimated by using time-series in situ data obtained at the HOT site in the subtropical North Pacific ${ }^{34}$. Since $\mathrm{N}_{2}$ fixation rates derived from the ${ }^{15} \mathrm{~N}_{2}$ dissolution method tend to be higher than those derived from ${ }^{15} \mathrm{~N}_{2}$ bubble method ${ }^{3,34,64}$, we used the data from ${ }^{15} \mathrm{~N}_{2}$ dissolution method in this study. As a large proportion of the $\mathrm{N}_{2}$ fixation occurred within the mixed layer ${ }^{3,65}$, we assumed integrated $\mathrm{N}_{2}$ fixation rates in the upper $125 \mathrm{~m}$ of the HOT site as the integrated $\mathrm{N}_{2}$ fixation rates in the $0 \sim 100 \mathrm{~m}$ layer in this study. The seasonal variation in the $\mathrm{N}_{2}$ fixation at the HOT site $\left(7.7 \times 10^{-5} \sim 3.6 \times 10^{-4} \mathrm{~mol} \mathrm{~N} \mathrm{~m}^{-2} \mathrm{~d}^{-1}\right)$ is the same order of magnitude as the discretely measured $\mathrm{N}_{2}$ fixation with the dissolution method in the euphotic zone $(<103 \sim 117 \mathrm{~m})$ of the western subtropical North Pacific $\left(20 \sim 23^{\circ}\right.$ $\mathrm{N}$ and $\left.137^{\circ} \mathrm{E} \sim 160^{\circ} \mathrm{W}\right)\left(3.5 \times 10^{-5} \sim 2.9 \times 10^{-4} \mathrm{~mol} \mathrm{~N} \mathrm{~m}^{-2} \mathrm{~d}^{-1}, n=10\right)^{3}$. Since the seasonal trend in the $\mathrm{N}_{2}$ fixation rates measured from the dissolution method remains unclear at the HOT site and the western subtropical North Pacific, we used a mean $\mathrm{N}_{2}$ fixation rate $\left(2.2 \times 10^{-4} \pm 6.4 \times 10^{-5} \mathrm{~mol} \mathrm{~N} \mathrm{~m}^{-2} \mathrm{~d}^{-1}\right)$ to calculate the integrated rate in each SST regime.

For atmospheric $\mathrm{N}$ and $\mathrm{P}$ depositions, in situ data over the oceanic area of the western subtropical North Pacific are limited and their seasonal trends remain unclear. Thus, we used mean deposition rates for bioavailable $\mathrm{N}\left(2.7 \times 10^{-5} \pm 5.7 \times\right.$ $\left.10^{-6} \mathrm{~mol} \mathrm{~N} \mathrm{~m}^{-2} \mathrm{~d}^{-1}\right)$ and $\mathrm{P}\left(8.4 \times 10^{-8} \pm 5.4 \times 10^{-8} \mathrm{~mol} \mathrm{P} \mathrm{m}^{-2} \mathrm{~d}^{-1}\right)$ taken from sites along a meridional transect through the western subtropical North Pacific during five cruises ${ }^{13}$ to calculate the integrated rate in each SST regime.

Calculation and statistical analyses. In this study, water column inventories of all sampled parameters were calculated by the trapezoidal rule. The errors with mean inventory, mean flux, and mean ratio were reported as $95 \%$ confidence interval (CI). For the error propagation when calculating mean value with addition, subtraction, or division, we adopted the following three equations, respectively ${ }^{66}$.

$$
\begin{gathered}
\left(M_{1} \pm E_{1}\right)+\left(M_{2} \pm E_{2}\right)=\left(M_{1}+M_{2}\right) \pm \sqrt{E_{1}^{2}+E_{2}^{2}} \\
\left(M_{1} \pm E_{1}\right)-\left(M_{2} \pm E_{2}\right)=\left(M_{1}-M_{2}\right) \pm \sqrt{E_{1}^{2}+E_{2}^{2}} \\
\frac{\left(M_{1} \pm E_{1}\right)}{\left(M_{2} \pm E_{2}\right)}=\frac{M_{1}}{M_{2}} \pm \frac{M_{1}}{M_{2}} \sqrt{\left(\frac{E_{1}}{M_{2}}\right)^{2}+\left(\frac{E_{2}}{M_{2}}\right)^{2}}
\end{gathered}
$$

where $M$ is mean and $E$ is $95 \% \mathrm{CI}$.

Statistical analyses were performed using XLSTAT premium ver. 2018.1.1.61323 (Addinsoft). A Friedman test was used to compare paired (same cruise) values of potential temperature or salinity at each depth between the four stations (except for Station 43). A two-sided Kruskal-Wallis test was used to compare the mean values of biogeochemical parameters between four different SST regimes or three different regional stations. Significance is reported where $P<0.05$, except for multiple comparisons with the Dunn's procedure after the Kruskal-Wallis tests. The significance of the multiple comparisons for four different SST regimes is reported where $P<0.0083$, as the Bonferroni correction was adopted. 
Data visualizations. To draw the distributions and fluxes of biogeochemical variables, we used Ocean Data View (ver. 5.2.1, https://odv.awi.de/), Kaleida Graph (ver. 4.5.1, Synergy Software), and Microsoft PowerPoint for Office 365. The color contours in Figs. 1, 2a, and 3a were drawn by the weighted-average griding of Ocean Data View with $x-y$ scale-lengths of 110-110, 65-65, and 40-30, respectively.

Reporting summary. Further information on research design is available in the Nature Research Reporting Summary linked to this article.

\section{Data availability}

Physical and biogeochemical data used in this study are available in the Supplementary Data 1 File that is deposited in the TUMSAT-OACIS site of Tokyo University of Marine Science and Technology (http://id.nii.ac.jp/1342/00002046/). The data including DIC and micromolar macronutrients that JMA measures routinely are also available from https:// www.data.jma.go.jp/gmd/kaiyou/db/vessel_obs/data-report/html/ship/ship_e.php and GLODAPv2 (https://www.glodap.info/). Data on monthly mean satellite SST (MODIS Aqua Level 3 SST MID-IR Monthly $4 \mathrm{~km}$ Nighttime V2019.0) were downloaded from the PODAAC site of NASA Earth Data (https://podaac.jpl.nasa.gov/). The monthly data of air-sea $\mathrm{CO}_{2}$ fluxes are taken from JMA's website at https://www.data.jma.go.jp/gmd/ kaiyou/english/co2_flux/co2_flux_data_en.html. Source data are provided with this paper.

Received: 16 December 2020; Accepted: 17 May 2021; Published online: 08 June 2021

\section{References}

1. Karl, D. M. et al. Ecological nitrogen-to-phosphorus stoichiometry at station ALOHA. Deep-Sea Res. II 48, 1529-1566 (2001).

2. Hashihama, F. et al. Macro-scale exhaustion of surface phosphate by dinitrogen fixation in the western North Pacific. Geophys. Res. Lett. 36, L03610 (2009).

3. Hashihama, F. et al. Biogeochemical controls of particulate phosphorus distribution across the oligotrophic subtropical Pacific Ocean. Glob. Biogeochem. Cycles 34, e2020GB006669 (2020).

4. Strickland, J. D. H. \& Parsons, T. R. A Practical Handbook of Seawater Analysis, 2nd edn. (Bull. Fish. Res. Board Can., 1972).

5. Letscher, R. T. \& Moore, J. K. Modest net autotrophy in the oligotrophic ocean. Glob. Biogeochem. Cycles 31, 699-708 (2017).

6. Emerson, S. Annual net community production and the biological carbon flux in the ocean. Glob. Biogeochem. Cycles 28, 14-28 (2014).

7. Michaels, A. F., Bates, N. R., Buesseler, K. O., Carlson, C. A. \& Knap, A. H. Carbon-cycle imbalances in the Sargasso Sea. Nature 372, 537-540 (1994).

8. Johnson, K. S., Riser, S. C. \& Karl, D. M. Nitrate supply from deep to near surface waters of the North Pacific subtropical gyre. Nature 465, 1062-1065 (2010).

9. Martiny, A. C. et al. Strong latitudinal patterns in the elemental ratios of marine plankton and organic matter. Nat. Geosci. 6, 279-283 (2013).

10. Baer, S. E., Lomas, M. W., Terpis, K. X., Mouginot, C. \& Martiny, A. C. Stoichiometry of Prochlorococcus, Synechococcus, and small eukaryotic populations in the western North Atlantic Ocean. Environ. Microbiol. 19, 1568-1583 (2017).

11. Karl, D. et al. The role of nitrogen fixation in biogeochemical cycling in the subtropical North Pacific Ocean. Nature 388, 533-538 (1997).

12. Duce, R. A. et al. Impacts of atmospheric anthropogenic nitrogen on the open ocean. Science 320, 893-897 (2008).

13. Martino, M. et al. Western Pacific atmospheric nutrient deposition fluxes, their impact on surface ocean productivity. Glob. Biogeochem. Cycles 28, 712-728 (2014).

14. Menzel, D. W. \& Ryther, J. H. The composition of particulate organic matter in the western North Atlantic. Limnol. Oceanogr. 9, 179-186 (1964).

15. Clark, L. L., Ingall, E. D. \& Benner, R. Marine phosphorus is selectively remineralized. Nature 393, 426 (1998)

16. Loh, A. N. \& Bauer, J. E. Distribution, partitioning and fluxes of dissolved and particulate organic C, N and P in the eastern North Pacific and Southern Oceans. Deep-Sea Res. I 47, 2287-2316 (2000).

17. Paytan, A., Cade-Menun, B. J., McLaughlin, K. \& Faul, K. L. Selective phosphorus regeneration of sinking marine particles: evidence from ${ }^{31} \mathrm{P}$ NMR. Mar. Chem. 82, 55-70 (2003).

18. Duhamel, S. et al. Growth and specific P-uptake rates of bacterial and phytoplanktonic communities in the Southeast Pacific (BIOSOPE cruise). Biogeosciences 4, 941-956 (2007).

19. Letscher, R. T. \& Moore, J. K. Preferential remineralization of dissolved organic phosphorus and non-Redfield DOM dynamics in the global ocean
Impacts on marine productivity, nitrogen fixation, and carbon export. Glob Biogeochem. Cycles 29, 325-340 (2015).

20. Martiny, A. C. et al. Biogeochemical controls of surface ocean phosphate. Sci. Adv. 5, eaax0341 (2019).

21. Hashihama, F. et al. Cross-basin differences in the nutrient assimilation characteristics of induced phytoplankton blooms in the subtropical Pacific waters. Biogeosciences 18, 897-915 (2021).

22. Dore, J. E., Lukas, R., Sadler, D. W. \& Karl, D. M. Climate-driven changes to the atmospheric $\mathrm{CO}_{2}$ sink in the subtropical North Pacific Ocean. Nature 424, 754-757 (2003).

23. Ishii, $\mathrm{M}$. et al. Seasonal variation in total inorganic carbon and its controlling processes in surface waters of the western North Pacific subtropical gyre. Mar. Chem. 75, 17-32 (2001)

24. Keeling, C. D., Brix, H. \& Gruber, N. Seasonal and long-term dynamics of the upper ocean carbon cycle at Station ALOHA near Hawaii. Glob. Biogeochem. Cycles 18, GB4006 (2004).

25. Dietze, H., Oschlies, A. \& Kahler, P. Internal-wave-induced and doublediffusive nutrient fluxes to the nutrient-consuming surface layer in the oligotrophic subtropical North Atlantic. Ocean Dynam. 54, 1-7 (2004)

26. Shiozaki, T. et al. Imbalance between vertical nitrate flux and nitrate assimilation on a continental shelf: Implications of nitrification. J. Geophys. Res. 116, C10031 (2011).

27. Zimmerman, A. E., Martiny, A. C., Lomas, M. W. \& Allison, S. D. Phosphate supply explains variation in nucleic acid allocation but not C:P stoichiometry in the western North Atlantic. Biogeosciences 11, 1599-1611 (2014).

28. Letelier, R. M., Karl, D. M., Abbott, M. R. \& Bidigare, R. R. Light driven seasonal patterns of chlorophyll and nitrate in the lower euphotic zone of the North Pacific Subtropical Gyre. Limnol. Oceanogr. 49, 508-519 (2004).

29. Kanda, J., Itoh, T. \& Nomura, M. Vertical profiles of trace nitrate in surface oceanic waters of the North Pacific Ocean and East China Sea. La mer. 45, 69-80 (2007).

30. Sañudo-Wilhelmy, S. A. et al. The impact of surface-adsorbed phosphorus on phytoplankton Redfield stoichiometry. Nature 432, 897-901 (2004).

31. Kamennaya, N. A., Geraki, K., Scanlan, D. J. \& Zubkov, M. V. Accumulation of ambient phosphate into the periplasm of marine bacteria is proton motive force dependent. Nat. Commun. 11, 2642 (2020).

32. Emerson, S. et al. Experimental determination of the organic carbon flux from open-ocean surface waters. Nature 389, 951-954 (1997).

33. Honda, M. C. et al. Impact of cyclonic eddies and typhoons on biogeochemistry in the oligotrophic ocean based on biogeochemical/physical/ meteorological time-series at station KEO. Prog. Earth Planet. Sci. 5, 42 (2018)

34. Böttjer, D. et al. Temporal variability of nitrogen fixation and particulate nitrogen export at Station ALOHA. Limnol. Oceanogr. 62, 200-216 (2017).

35. Sato, M., Sakuraba, R. \& Hashihama, F. Phosphate monoesterase and diesterase activities in the North and South Pacific Ocean. Biogeosciences 10, 7677-7688 (2013)

36. Lomas, M. W. et al. Sargasso Sea phosphorus biogeochemistry: an important role for dissolved organic phosphorus (DOP). Biogeosciences 7, 695-710 (2010).

37. Letscher, R. T., Primeau, F. \& Moore, J. K. Nutrient budgets in the subtropical ocean gyres dominated by lateral transport. Nat. Geosci. 9, 815-819 (2016).

38. Hashihama, F. et al. Arsenate and microbial dynamics in different phosphorus regimes of the subtropical Pacific Ocean. Prog. Oceanogr. 176, 102115 (2019).

39. Dugdale, R. C. \& Goering, J. J. Uptake of new and regenerated forms of nitrogen in primary productivity. Limnol. Oceanogr. 12, 196-206 (1967)

40. Perry, M. J. \& Eppley, R. W. Phosphate uptake by phytoplankton in the central North Pacific Ocean. Deep-Sea Res. 28, 39-49 (1981)

41. Regaudie-De-Gioux, A., Lasternas, S. B., Agustí, S. \& Duarte, C. M. Comparing marine primary production estimates through different methods and development of conversion equations. Front. Mar. Sci. 1, 19 (2014).

42. Jiang, H.-B. et al. Ocean warming alleviates iron limitation of marine nitrogen fixation. Nat. Clim. Change 8, 709-712 (2018)

43. Jickells, T. D. et al. A reevaluation of the magnitude and impacts of anthropogenic atmospheric nitrogen inputs on the ocean. Glob. Biogeochem. Cycles 31, 289-305 (2017)

44. de Boyer Montégut, C., Madec, G., Fischer, A. S., Lazar, A. \& Iudicone, D. Mixed layer depth over the global ocean: An examination of profile data and a profile-based climatology. J. Geophys. Res. 109, C12003 (2004)

45. Ryther, J. H. Photosynthesis in the ocean as a function of light intensity Limnol. Oceanogr. 1, 61-69 (1956).

46. Kilpatrick, K. A. et al. A decade of sea surface temperature from MODIS. Remote Sens. Environ. 165, 27-41 (2015).

47. Dickson, A. G., Afghan, J. D. \& Anderson, G. C. Reference materials for oceanic $\mathrm{CO}_{2}$ analysis: a method for the certification of total alkalinity. Mar. Chem. 80, 185-197 (2003).

48. Hashihama, F., Kanda, J., Maeda, Y., Ogawa, H. \& Furuya, K. Selective depressions of surface silicic acid within cyclonic mesoscale eddies in the oligotrophic western North Pacific. Deep-Sea Res. I 90, 115-124 (2014). 
49. Hansen, H. P. \& Koroleff, F. in Methods of Seawater Analysis, 3rd edn (eds Grasshoff, K., Kremling, K. \& Ehrhardt, D.) 159-228 (Wiley, 1999).

50. Goto, Y., Yasuda, I. \& Nagasawa, M. Turbulence estimation using fastresponse thermistors attached to a free-fall vertical microstructure profiler. $J$. Atmo. Ocean. Technol. 33, 2065-2078 (2016).

51. Goto, Y., Yasuda, I. \& Nagasawa, M. Comparison of turbulence intensity from CTD-attached and free-fall microstructure profilers. J. Atmo. Ocean. Technol. 35, 147-162 (2018).

52. Nishioka, J. et al. Subpolar marginal seas fuel the North Pacific through the intermediate water at the termination of the global ocean circulation. Proc. Natl Acad. Sci. USA 117, 12665-12673 (2020).

53. Yasuda, I. et al. Estimate of turbulent energy dissipation rate using free-fall and CTD-attached fast-response thermistors in weak ocean turbulence. J. Oceanogr. 77, 17-28 (2021).

54. Ehama, M., Hashihama, F., Kinouchi, S., Kanda, J. \& Saito, H. Sensitive determination of total particulate phosphorus and particulate inorganic phosphorus in seawater using liquid waveguide spectrophotometry. Talanta 153, 66-70 (2016)

55. Suzumura, M. Persulfate chemical wet oxidation method for the determination of particulate phosphorus in comparison with a hightemperature dry combustion method. Limnol. Oceanogr. Methods 6, 619-629 (2008).

56. Miyata, K. \& Hattori, A. A simple fractionation method for determination of phosphorus components in phytoplankton: application to natural populations of phytoplankton in summer surface waters of Tokyo Bay. J. Oceanogr. Soc. Jpn. 42, 255-265 (1986).

57. Sato, M. \& Hashihama, F. Assessment of potential phagotrophy by pico- and nanophytoplankton in the North Pacific Ocean using flow cytometry. Aquat. Microb. Ecol. 82, 275-288 (2019).

58. Marie, D., Partensky, F., Jacquet, S. \& Vaulot, D. Enumeration and cell cycle analysis of natural populations of marine picoplankton by flow cytometry using the nucleic acid stain SYBR Green I. Appl. Environ. Microbiol. 63, 186-193 (1997).

59. Sato, M., Hashihama, F., Kitajima, S., Takeda, S. \& Furuya, K. Distribution of nano-sized Cyanobacteria in the western and central Pacific Ocean. Aqua. Microb. Ecol. 59, 273-278 (2010).

60. Villareal, T. A. et al. Upward transport of oceanic nitrate by migrating diatom mats. Nature 397, 423-425 (1999).

61. Letscher, R. T. \& Villareal, T. A. Evaluation of the seasonal formation of subsurface negative preformed nitrate anomalies in the subtropical North Pacific and North Atlantic. Biogeosciences 15, 6461-6480 (2018).

62. Utermöhl, H. Zur Vervollkommung der quantitativen PhytolanktonMethodik. Mitt. Int. Ver. Limnol. 9, 1-39 (1958).

63. Iida, Y., Takatani, Y., Kojima, A. \& Ishii, M. Global trends of ocean $\mathrm{CO}_{2}$ sink and ocean acidification: an observation-based reconstruction of surface ocean inorganic carbon variables. J. Oceanogr. 77, 323-358 (2021).

64. Mohr, W., Großkopf, T., Wallace, D. W. R. \& Laroche, J. Methodological underestimation of oceanic nitrogen fixation rates. PLOS ONE 5, e12583 (2010).

65. Luo, Y.-W. et al. Database of diazotrophs in global ocean: abundance, biomass and nitrogen fixation rates. Earth Sys. Sci. Data 4, 47-73 (2012).

66. Miller, J. C. \& Miller, J. N. Statistics for Analytical Chemistry, 2nd edn. (Ellis Horwood, 1993).

\section{Acknowledgements}

We thank the officers, crew, scientists of the R/V Keifu-maru and R/V Ryofu-maru, and the staff of the Global Environment and Marine Department, Japan Meteorological Agency for their cooperation in this study. Data on atmospheric depositions of $\mathrm{N}$ and $\mathrm{P}$ were provided by A.R. Baker. This work was financially supported by JSPS/MEXT KAKENHI Nos. 24121001 (K.F.), 24121003 (H. Saito, M.I., and F.H.), 24121005 (K.F.), 24121006 (M.S.), 15H02802 (J.K. and F.H.), 15H05817 (I.Y), 15H05818 (I.Y.), 16H01594 (M.I.), $17 \mathrm{H} 01852$ (F.H. and J.K.), and 20H05598 (I.Y.).

\section{Author contributions}

F.H. and M.I. designed this study under the JSPS/MEXT KAKENHI projects supervised by K.F. and H. Saito. F.H. collected the sample from the western subtropical North Pacific. F.H. and J.K. conducted sensitive macronutrient analysis. I.Y. processed $K_{z}$ data H. Sasaoka analyzed the chemical fraction of TPP. A.K. and M.S. conducted FCM for microbial analysis. Y.I. processed air-sea $\mathrm{CO}_{2}$ flux data. T.S. and K.F. controlled data collection of marine $\mathrm{N}_{2}$ fixation from the western subtropical North Pacific. F.H., T.S., M.I., and P.W.B. wrote the manuscript with contributions from all co-authors.

\section{Competing interests}

The authors declare no competing interests.

\section{Additional information}

Supplementary information The online version contains supplementary material available at https://doi.org/10.1038/s41467-021-23837-y.

Correspondence and requests for materials should be addressed to F.H.

Peer review information Nature Communications thanks Solange Duhamel, Allison Moreno, and other, anonymous, reviewers for their contributions to the peer review of this work. Peer review reports are available.

Reprints and permission information is available at http://www.nature.com/reprints

Publisher's note Springer Nature remains neutral with regard to jurisdictional claims in published maps and institutional affiliations.

pen Access This article is licensed under a Creative Commons Attribution 4.0 International License, which permits use, sharing, adaptation, distribution and reproduction in any medium or format, as long as you give appropriate credit to the original author(s) and the source, provide a link to the Creative Commons license, and indicate if changes were made. The images or other third party material in this article are included in the article's Creative Commons license, unless indicated otherwise in a credit line to the material. If material is not included in the article's Creative Commons license and your intended use is not permitted by statutory regulation or exceeds the permitted use, you will need to obtain permission directly from the copyright holder. To view a copy of this license, visit http://creativecommons.org/ licenses/by/4.0/.

(C) The Author(s) 2021 